\title{
Osteogenic Effect of Inducible Nitric Oxide Synthase (iNOS)-Loaded Mineralized Nanoparticles on Embryonic Stem Cells
}

\author{
Jin-Sun Lee Hong Jae Lee Jae Won Lee Sang Cheon Lee Jung Sun Heo \\ Department of Maxillofacial Biomedical Engineering and Institute of Oral Biology, School of Dentistry, \\ Kyung Hee University, Seoul, South Korea
}

\section{Key Words}

Embryonic stem cells - Inducible nitric oxide synthase $\cdot$ Mineralized nanoparticle - Nitric oxide - Osteogenic differentiation

\begin{abstract}
Background/Aims: This study investigated the effect of inducible nitric oxide synthase-loaded mineralized nanoparticles (iNOS-MNPs) on the osteogenic differentiation of mouse embryonic stem cells (ESCs). Methods: We prepared iNOS-MNPs using an anionic block copolymer template-mediated calcium carbonate $\left(\mathrm{CaCO}_{3}\right)$ mineralization process in the presence of iNOS. iNOS-MNPs were spherical and had a narrow size distribution. iNOS was stably loaded within MNPs without denaturation. In order to confirm the successful introduction of iNOSMNPs into the cytosol of ESCs, intracellular levels of nitric oxide (NO) was determined with a fluorometric analysis. A NO effector molecule, cyclic guanosine $3^{\prime}, 5^{\prime}$ monophosphate (cGMP) was also quantified with a competitive enzyme immunoassay. Cell viability in response to iNOS-MNP treatment was determined using the cell counting kit-8 (CCK-8) assay. Alkaline phosphatase (ALP) activity assay, intracellular calcium quantification assay, and Alizarin red $\mathrm{S}$ staining for matrix mineralization were performed to investigate osteogenic differentiation of ESCs. The protein levels of Runt-related transcription factor 2 (RUNX2), osteocalcin (OCN), and osterix (OSX) as osteogenic-related factors were also assessed by immunofluorescence staining and Western blot analysis. The complex pathways associated with iNOS-MNP-derived osteogenic differentiation of ESCs were evaluated by network-based analysis. Results: Cells with iNOS-MNPs displayed a significant increase in NO and cGMP concentration compared with the control group. When cells were exposed to iNOS-MNPs, there were no adverse effects on cell viability. Importantly, iNOS-MNP uptake promoted the osteogenic differentiation of ESCs. Using transcriptome profiling, we obtained 1,836 differentially-induced genes and performed functional enrichment analysis with ClueGO and KEGG. These analyses identified significantly enriched and interconnected molecular pathways such as protein kinase activity, estrogen receptor activity, bone morphogenetic protein (BMP) receptor binding, ligand-
\end{abstract}

Sang Cheon Lee, Ph.D and Jung Sun Heo, D.V.M. Ph.D
Department of Maxillofacial Biomedical Engineering and Institute of Oral Biology, School of Dentistry, Kyung Hee University, 26 Kyunghee-daero, Dongdaemun-gu, Seoul 02447 (South Korea) Tel. +82-2-961-0470,E-Mail schlee@khu.ac.kr; heojs@khu.ac.kr 


\section{Cellular Physiology Cell Physiol Biochem 2018;51:746-762

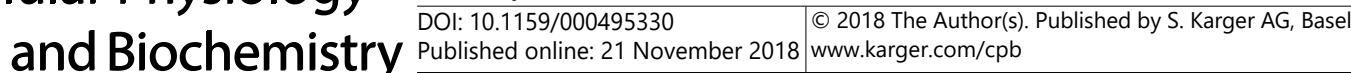 \\ Lee et al.: Effect of iNOS-MNP-Derived NO on ESC Osteogenesis}

gated ion channel activity, and phosphatidylinositol 3-phosphate binding. Conclusion: These findings suggest that iNOS-MNPs can induce osteogenic differentiation in ESCs by integrating complex signaling pathways.

(c) 2018 The Author(s)

Published by S. Karger AG, Basel

\section{Introduction}

Nitric oxide is a highly reactive free radical produced from a guanidino-nitrogen of L-arginine by three isoforms of nitric oxide synthases (NOS), including endothelial NOS (eNOS), neuronal NOS (nNOS), and inducible NOS (iNOS), depending on tissue location and physiological function [1-3]. Specifically, iNOS and eNOS are expressed in bone marrow stromal cells, osteoblasts, osteocytes, and osteoclasts, whereas nNOS expression is restricted to the bone lining cells and osteoclasts [4]. While all three NOS isoforms have been implicated in the bone healing process [5-7] iNOS is the principal isoform involved in the stimulation of osteoblasts by NO production [8-10].

NO is a signaling molecule that mediates a number of physiological events [11, 12]. NO has been shown to play an important role in bone formation and healing processes and can be generated by many cell types present in the bone milieu, most significantly, the osteoblasts [13]. However, whether NO results in pluripotent stem cell commitment into the osteogenic lineage has not been characterized.

NO-induced cyclic guanosine 3',5' monophosphate (cGMP) plays an important role in the early lineage specification of embryonic stem cells (ESCs) [14, 15]. ESCs treated with high concentrations of a chemical NO donor downregulated pluripotent gene expression and promoted differentiation events [16]. A number of groups have demonstrated that NO encourages the differentiation of bone marrow-derived mesenchymal stem cells (MSCs) into osteoprogenitor cells [17-19]. However, whether NO is associated with the osteogenic differentiation of ESCs in vitro remains largely unknown [20,21].

NO is an important cellular signaling molecule that regulates stem cell fate. However, NO exists as a gas, which limits its use for research. Thus, NO-generating chemical compounds have been developed as NO donors and utilized in vitro and in vivo [22, 23], but are inconvenient due to their short half-life, cell toxicity, and low stability. In this study, we developed iNOS-loaded nanoparticles, which are manufactured through non-toxic processes using biocompatible polyethylene glycol (PEG)-poly L-aspartic acid (PAsp) block copolymerinduced mineralization for controlled, intracellular NO generation. Intracellular delivery of functional proteins, including enzymes, regulates various cellular events and has therapeutic applications in animal studies [24,25]. The stable delivery and controlled release of iNOS enzyme in cells and the sustained production of NO molecules may mimic physiological NO production. Therefore, our system can overcome the limitations of current methods of NO application in biological experiments.

Nanomaterials can control stem cell behavior and tissue regeneration. Therefore, organic and inorganic nanoparticles are commonly used in stem cell research [26]. In this way, establishment of nanomaterial-based methodologies for ESC differentiation may provide a real-time toolkit for exploring a role for stem cell differentiation in cell therapy. In the present study, we demonstrate the effective delivery of iNOS-loaded nanoparticles into ESCs. Additionally, using global gene expression profiling for iNOS-MNP-mediated ESC osteogenesis, we assess the pro-osteogenic impact of iNOS-mediated NO production on ESCs and the activation of intracellular NO-related signaling pathways. 


\section{Cellular Physiology Cell Physiol Biochem 2018;51:746-762

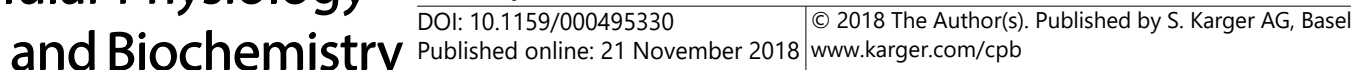 \\ Lee et al.: Effect of iNOS-MNP-Derived NO on ESC Osteogenesis}

\section{Materials and Methods}

\section{Materials}

Fetal bovine serum (FBS) was purchased from Gibco-BRL (Gaithersburg, MD, USA). $\alpha$-Methoxy$\omega$-amino-poly(ethylene glycol) $\left(\mathrm{CH}_{3} \mathrm{O}-\mathrm{PEG}-\mathrm{NH}_{2}\right)$ with an average molecular weight of 5, $000 \mathrm{~g} / \mathrm{mol}$ was purchased from IDBIOCHEM Inc. (Seoul, Korea). A poly(ethylene glycol)-b-poly(L-aspartic acid) copolymer (PEG-PAsp) containing 113 EG units and 32 Asp units was synthesized by a modified procedure established in our laboratory [Min KH]. Inducible nitric oxide synthease (iNOS) was purchased from Sigma Co. (St. Louis, MO) and used as received. Reagent grade calcium chloride $\left(\mathrm{CaCl}_{2}\right)$ and sodium carbonate $\left(\mathrm{Na}_{2} \mathrm{CO}_{3}\right)$ were utilized. Unless otherwise specified, laboratory supplies and chemicals were purchased from SPL Lifescience (Pocheon, Korea) and Sigma Chemical Company.

\section{Fabrication of iNOS-loaded $\mathrm{CaCO}_{3}$-Mineralized Nanoparticles (iNOS-MNPs).}

iNOS was loaded into the $\mathrm{CaCO}_{3}$-mineralized nanoparticles by the PEG-PAsp-templated mineralization process as follows. To a stirred aqueous PEG-PAsp solution $(2.5 \mathrm{mg} / \mathrm{mL}, \mathrm{pH} 8.0)$, an aqueous solution of calcium chloride ( $2 \mathrm{~mL}, 0.037 \mathrm{mmol}$, pH 8.0) was added at room temperature. After $2 \mathrm{~h}$, an aqueous solution of iNOS (20 UN, pH 8.0) was added into the solution, and the solution mixture was stirred at $500 \mathrm{rpm}$ for $3 \mathrm{~h}$. Then, the aqueous solution of sodium carbonate $(0.037 \mathrm{mmol}, \mathrm{pH} 8.0)$ was slowly mixed, and the mixture was vigorously stirred at $1,000 \mathrm{rpm}$ at $4^{\circ} \mathrm{C}$ for $24 \mathrm{~h}$. After centrifugation at $3,000 \mathrm{rpm}$ for $3 \mathrm{~min}$, the supernatant was placed into a membrane bag for dialysis against doubly distilled water (pH 8.0, molecular weight cut-off (MWCO): 100, $000 \mathrm{~g} / \mathrm{mol}$ ) for $12 \mathrm{~h}$, followed by freeze-drying. For calculation of the loading amount of iNOS in the iNOS-MNPs, the iNOS-MNPs were completely dissolved in doubly distilled water (pH 5.0 ), and the iNOS was quantified using a quantification assay kit for iNOS.

\section{Characterization of the iNOS-MNPS}

Dynamic light scattering measurements were performed using a 90 Plus particle size analyzer (Brookhaven Instruments Corporation) equipped with a vertically-polarized He-Ne laser (632.8 $\mathrm{nm}$ ). The hydrodynamic diameter (d) and polydispersity factor (PDF) of the iNOS-MNPs were calculated using the Stokes-Einstein equation and the cumulant method, respectively [Harada A]. The morphology of the iNOSMNPs was examined by transmission electron microscopy (TEM; H-7100, HITACHI, Japan), operating at an acceleration voltage of $100 \mathrm{kV}$. For the observation of size and morphology of the iNOS-MNPs, a drop of sample solution (concentration $=1 \mathrm{~g} / \mathrm{L}$ ) was placed onto a 200-mesh copper grid coated with carbon. About 5 min after deposition, the grid was tapped with a filter paper to remove surface water, followed by airdrying. Fourier transform infrared (FT-IR) spectra of the iNOS-MNPs were obtained using a Spectrum One System FT-IR spectrometer (Perkin Elmer, New York, USA) in the range of 450 to $2000 \mathrm{~cm}^{-1}$ at a resolution of $4 \mathrm{~cm}^{-1}$.

\section{Estimation of pH-dependent catalytic activity of iNOS-MNPs for NO generation}

The activities of the iNOS-MNPs for NO generation were evaluated by estimating the nitrite generation in a HEPES-buffered solution (20 mM, $0.5 \mathrm{mM}$ EDTA) at pH 7.4 and 5.0 at $37^{\circ} \mathrm{C}$. The iNOS-MNPs were dispersed in buffer solutions ( $1 \mathrm{~mL}, 1 \mathrm{mg} / \mathrm{mL}$ ) at $\mathrm{pH} 7.4$ and 5.0, and the time-dependent nitrite generation was quantified using an ultrasensitive colorimetric assay kit for iNOS (NB78, Oxford Biomedical Research Inc.). The medium was shaken at a speed of $100 \mathrm{rpm}$ at $37^{\circ} \mathrm{C}$. At pre-determined time intervals, samples $(100 \mu \mathrm{l})$ were withdrawn and replaced with an equal volume of the fresh medium. The nitrite concentration was determined by interpolation from the nitrite standard curve.

\section{pH-dependent dissolution of iNOS-MNPS}

To study iNOS release, in vitro dissolution behavior of iNOS-MNPs was estimated in the buffer solutions (pH 7.4 and pH 5.0). The iNOS-MNP solution $(1 \mathrm{mg} / \mathrm{mL}$ ) was placed in a dialysis membrane bag (MWCO: 3, $500 \mathrm{~g} / \mathrm{mol})$ and was shaken at $100 \mathrm{rpm}$ at $37^{\circ} \mathrm{C}$ in the release medium. The release medium $(10 \mathrm{~mL}) \mathrm{was}$ withdrawn at predetermined time intervals and replaced with an equal volume of the fresh medium. The release rate of calcium ions was monitored by diluting $100 \mu \mathrm{l}$ of sample with the Arsenazo III solution (2 


\section{Cellular Physiology Cell Physiol Biochem 2018;51:746-762 and Biochemistry \begin{tabular}{l|l} 
DOI: 10.1159/000495330 & (c) 2018 The Author(s). Published by S. Karger AG, Basel \\
wublished
\end{tabular}

$\mathrm{mL}, 0.2 \mathrm{mM}$ ) in HBS (HEPES-buffered saline where $[\mathrm{HEPES}]=20 \mathrm{mM}$ and $[\mathrm{NaCl}]=150 \mathrm{mM}$ at $\mathrm{pH} 7.4$ ). The absorbance of Arsenazo III/ $\mathrm{Ca}^{2+}$ complex in the solution was measured at $656 \mathrm{~nm}$, and the concentration of calcium ions was calculated based on the standard curve.

Mouse ESC culture and embryoid body formation

Mouse ESCs [ES-E14TG2a $\left(\right.$ ATCC $^{\circledR}$ CRL-1821 ${ }^{\mathrm{TM}}$ )] were obtained from the American Type Culture Collection (Manassas, VA, USA). The ESCs were cultured in Dulbecco's modified Eagle's medium (DMEM) (Gibco-BRL, USA) supplemented with $17.5 \mathrm{mM}$ glucose, $1.7 \mathrm{mM}$ L-glutamine, $0.1 \mathrm{mM} \beta$-mercaptoethanol, $5 \mathrm{ng} / \mathrm{ml}$ mouse leukemia inhibitory factor (LIF, Enzo Life Sciences, USA), 15\% FBS, and 1\% penicillin and streptomycin (Gibco-BRL, USA), without a feeder layer at $37^{\circ} \mathrm{C}$ in an atmosphere containing $5 \% \mathrm{CO}_{2}$. To form embryoid bodies (EBs), the cells were dissociated by $0.05 \%$ trypsin/EDTA (Gibco-BRL, USA). Then, 2, 000 cells were hung from the lids of $150 \mathrm{~mm}$ culture dishes for 2 days in $20 \mu \mathrm{l}$ DMEM without LIF. EBs were then suspended in additional medium for 3 days. Thus, EBs cultured for 5 days old were used in this experiment.

\section{Osteogenic differentiation of ESCs}

ESC differentiation was performed as previously reported. EBs were plated onto gelatin-coated 60mm dishes (10-15 EBs per well) and maintained in an osteogenic medium consisting of DMEM with 5\% FBS, $50 \mu \mathrm{g} / \mathrm{mL}$ ascorbic acid, $1 \mu \mathrm{M}$ dexamethasone, and $3 \mathrm{mM} \beta$-glycerophosphate for 2 days before the application of iNOS-MNPs. To promote osteogenic differentiation, iNOS-MNPs at different concentrations $(0$ to $100 \mu \mathrm{g} / \mathrm{ml}$ ) were added to the osteogenic medium, which was changed every other day.

\section{Measurement of nitric oxide}

4-Amino-5-methylamino-2',7'-difluorofluorescein diacetate (DAF-FM DA) was used for fluorescence microscopy of NO and measurements of NO production. For microscopy studies, EBs were cultured in 6-well plates and treated for the indicated times with different drug concentrations. Cells were washed and phenol red-free media was added, and then cells were incubated with DAF-FM DA (5 $\mu \mathrm{M})$ for 10 min in the dark. Cells were then washed twice with ice-cold phosphate-buffered saline (PBS) and fixed with $2 \%$ paraformaldehyde for $3 \mathrm{~min}$ and washed twice again with ice-cold PBS. Analysis of NO production was carried out using a fluorescence microscope (Fluoview 300, Olympus, Japan) with the excitation wavelength set at $480 \pm 10 \mathrm{~nm}$ and the emission wavelength at $505 \pm 10 \mathrm{~nm}$. For fluorometry experiments, cells were cultured with iNOSMNPs (10 $\mu \mathrm{g} / \mathrm{ml})$. After 24, 48, and $72 \mathrm{~h}$, cells were washed twice with ice-cold PBS and incubated with DAFFM DA $(5 \mu \mathrm{M})$ at $37^{\circ} \mathrm{C}$. Following incubation for $1 \mathrm{~h}$, NO levels were determined by fluorescence readings using a fluorometer (Triad, DYNEX, Austria) with the excitation and emission wavelengths set at $490 \mathrm{~nm}$ and $515 \mathrm{~nm}$, respectively. 'No dye' controls were used as background fluorescence and were subtracted from 'all dye'-containing sample well readings.

\section{Measurement of cGMP levels}

The cells were incubated for 2 days in osteogenic differentiation media containing different concentrations of iNOS-MNPs. Cells were washed three time with PBS and lysed in lysis buffer from the cGMP ELISA kit (CELL BIOLABS, USA.). Total protein content was quantified using the Bradford method [27]. The cGMP content was measured using a cGMP ELISA kit according to the manufacturer's instructions and the absorbance was read at $450 \mathrm{~nm}$ using a spectrophotometer. The cGMP content level was expressed as $\mathrm{pmol} / \mathrm{mg}$ of protein.

\section{Cell Viability assay}

Cell viability was analyzed by using the cell counting kit-8 (CCK-8) assay. Briefly, EBs were seeded into 60-mm culture dishes. After $24 \mathrm{~h}$, cells were changed to DMEM medium containing 5\% FBS, and maintained for $24 \mathrm{~h}$. Then, cells were incubated with different concentrations of iNOS-MNPs $(0-100 \mu \mathrm{g} /$ $\mathrm{ml}$ ) for 24 or $48 \mathrm{~h}$. After exposure, CCK-8 solution was added for $1 \mathrm{~h}$ and the assay was performed following the manufacturer's instructions. The optical density of each well was determined at a wavelength of $450 \mathrm{~nm}$ using an ELISA plate reader (Triad, DYNEX, Austria). The percentage of cell viability was calculated relative to the control. 


\section{Cellular Physiology Cell Physiol Biochem 2018;51:746-762

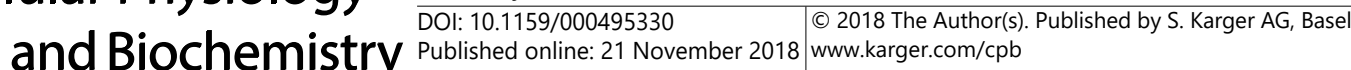

Lee et al.: Effect of iNOS-MNP-Derived NO on ESC Osteogenesis

\section{Measurement of ALP activity}

Cells were plated onto gelatin-coated 60-mm dishes (10-15 EBs per well). After $48 \mathrm{~h}$ since seeding, cells were changed into osteogenic differentiation medium containing different concentration of iNOS-MNPs $(0-100 \mu \mathrm{g} / \mathrm{ml})$. Total cells were lysed in $50 \mathrm{mM}$ Tris- $\mathrm{HCl}$ buffer ( $\mathrm{pH} 7.0)$ containing $1 \%(\mathrm{v} / \mathrm{v})$ Triton X-100 and $1 \mathrm{mM}$ phenylmethylsulfonyl fluoride (PMSF). Total protein content was quantified using the Bradford assay. ALP activity was evaluated at 4 and 7 days by using $p$-nitrophenylphosphate (pNPP) method. The cell lysate was assayed by adding $200 \mu \mathrm{l}$ of pNPP as a substrate (Sigma) for $30 \mathrm{~min}$ at $37^{\circ} \mathrm{C}$. The reaction was stopped by adding $3 \mathrm{M} \mathrm{NaOH}$, and the result was read at a wavelength of $405 \mathrm{~nm}$ using a spectrophotometer. The enzyme activity was expressed as $\mathrm{mM} / 100 \mu \mathrm{g}$ of protein.

\section{Intracellular calcium quantification assay}

Cells were plated onto gelatin-coated 60-mm dishes (10-15 EBs per well). Forty -eight hours after seeding, cells were changed into osteogenic differentiation medium containing different concentration of iNOS-MNPs (0-100 $\mathrm{\mu g} / \mathrm{ml})$. After 14 days, cells were washed three times using PBS and lysed in $50 \mathrm{mM}$ Tris$\mathrm{HCl}$ buffer (pH 7.0) containing $1 \mathrm{mM}$ PMSF and 1\% (v/v) Triton X-100 without EDTA. Total protein content was quantified using the Bradford method. Intracellular calcium was measured using a calcium assay kit according to the manufacturer's instructions. The absorbance was read at $612 \mathrm{~nm}$ using an ELISA plate reader. The calcium content level was expressed as $\mathrm{mM} / 100 \mathrm{mg}$ of protein.

\section{Alizarin red S staining}

Cells were plated onto gelatin-coated 12-well culture plates (5 EBs per well) and incubated in osteogenic medium for 21 days. The culture media was aspirated and washed three times with PBS. Cells were fixed in $4 \%$ paraformaldehyde for $20 \mathrm{~min}$, washed three times with ice-cold PBS, and stained with $2 \%$ alizarin red S solution ( $\mathrm{pH} \mathrm{4.2)} \mathrm{for} 5 \mathrm{~min}$ at room temperature. Finally, the alizarin red S solution was aspirated and washed with deionized water. The samples were observed under a light microscope.

\section{RNA isolation and real-time reverse transcriptase-polymerase chain reaction (RT-PCR)}

Gene expression of Mmp15, Cltb, Atp5s, Cadn4, Wnt9a, Bmp8a, Fgf11, Map4k1 were analyzed by using real-time RT-PCR. Total RNA was extracted from different groups at 4 days by using the TRIzol reagent, following the manufacturer's instructions. cDNA was synthesized using the cDNA synthase kit (Bioneer, Korea) in accordance with the manufacturer's instructions. Real time RT-PCR was performed in the RotorGene 2000 real-time thermal cycling system (Corbett Research, Sydney, Australia) using a QuantiTect SYBR Green RT-PCR kit (Enzo, USA). The mouse primers used were $5^{\prime}$-ATC TGG CGG TCT GGA AGA AC-3' (forward), $5^{\prime}$-AGG CTG CCC AAA ATC CAA TC-3' (reverse) for Mmp15, 5'-CTT TCA CCC CAC AAC TCC TT-3' (forward), 5'-CAC AAT TGA GTG GGC TGA CA-3' (reverse) for Cltb, 5'-TCA CTG CTG GAA TCC ACT GT-3' (forward), $5^{\prime}$ AAA TCC CGG GAA GCC ATA C-3' (reverse) for Atp5s, 5'-CCC TCT CCC CCC ATT ACT G-3' (forward), $5^{\prime}$-GCC CCG TAC AAA AAT GTG TT-3' (reverse) for Cadn4, 5'-TCT TGT GCA GCC TGT GAT TT-3' (forward), 5'-TTC TCT GCA GTC ACT CAG GTT-3' (reverse) for Wnt9a, 5'-CAG CCA AAG AAA ACG AAC GA-3' (forward), 5'-AAC CGT GGC CAT CAT CAA AG-3' (reverse) for Bmp8a, 5'-ACC CCC AAC TCA GCA ATA AG-3' (forward), 5'-GAG GCT CCT CGT TTC CTA AG-3' (reverse) for Fgf11, 5'-ATT GGG ACA CCG TAC TGG AT-3' (forward), 5'-TGT CGC ACA GCT CAT TGT AT-3' (reverse) for Map4k1, 5'-TGC ACC ACC AAC TGC TTA G-3' (forward), 5'-GGA TGC AGG GAT GAT GTT C-3' (reverse) for GAPDH. The reaction mixture contained $1 \mu \mathrm{g}$ of the total RNA and $0.5 \mu \mathrm{M}$ of each primer. Real-time RT-PCR was performed using the Rotor-Gene 2000 cycler program: $30 \mathrm{~min}$ at $50^{\circ} \mathrm{C}$ for reverse transcription; $15 \mathrm{~min}$ at $95^{\circ} \mathrm{C}$ for DNA polymerase activation; $15 \mathrm{sec}$ at $95^{\circ} \mathrm{C}$ for denaturing; and 45 cycles of $15 \mathrm{sec}$ at $94^{\circ} \mathrm{C}, 30 \mathrm{sec}$ at $60^{\circ} \mathrm{C}$, and $30 \mathrm{sec}$ at $72^{\circ} \mathrm{C}$. Data collection was carried out during the extension step ( $30 \mathrm{sec}$ at $72^{\circ} \mathrm{C}$ ). RNA expression levels of target genes were normalized to control GAPDH RNA expression. The temperature of the PCR products was increased from 65 to $99^{\circ} \mathrm{C}$ at a rate of $1^{\circ} \mathrm{C} / 5 \mathrm{sec}$, and the resulting data was analyzed using the software provided by the manufacturer.

\section{Immunofluorescence staining}

Cells were incubated for 4 days in osteogenic differentiation medium containing iNOS-MNPs, washed three times with PBS, fixed for $5 \mathrm{~min}$ using $4 \%$ paraformaldehyde and permeabilized for 20 min using $0.1 \%$ Triton X-100 at room temperature. Then, cells were washed three times and blocked for $1 \mathrm{~h}$ using $4 \%$ BSA in PBS at room temperature. The cells were treated with primary antibody $(1: 100$, rabbit anti-OCN, rabbit anti- 


\section{Cellular Physiology Cell Physiol Biochem 2018;51:746-762 and Biochemistry \begin{tabular}{l|l} 
DOI: IO.T159/000495330 & (c) 2018 The Author(s). Published by S. Karger AG, Basel \\
www.karger.com/cpb
\end{tabular} \\ Lee et al.: Effect of iNOS-MNP-Derived NO on ESC Osteogenesis}

RUNX2) and overnight incubation at $4^{\circ} \mathrm{C}$. Subsequently, cells were treated with Alexa Fluor 488 or 594 goat anti-rabbit immunoglobulin G (IgG) (1:500, Invitrogen Life Technologies, USA) for $2 \mathrm{~h}$ at room temperature. Fluorescence images were obtained using a fluorescence microscope (Fluoview 300, Olympus, Japan).

\section{Western blot analysis}

The cells were incubated for 7 days in osteogenic differentiation medium containing different concentrations iNOS-MNPs. Whole cells were lysed using RIPA buffer with protease inhibitor and protein contents were quantified using the Bradford procedure. Protein extracts (30 $\mu \mathrm{g}$ ) were separated by $10 \%$ sodium dodecyl sulfate polyacrylamide gel and blotted onto polyvinylidene difluoride (PVDF) membranes. The blots were washed with $10 \mathrm{mM}$ Tris-HCl (pH 7.6), $150 \mathrm{mM} \mathrm{NaCl}, 0.05 \%$ Tween-20 (TBST), blocked with 5\% skim milk for $1 \mathrm{~h}$ and incubated with the appropriate primary antibodies (anti-OCN, anti-OSX, and anti- $\beta$-actin) at the dilutions recommended by the supplier at $4{ }^{\circ} \mathrm{C}$ overnight. The membranes were then washed and the bound primary antibodies were detected with goat anti-rabbit IgG or goat anti-mouse IgG conjugated to horseradish peroxidase. The blots were developed with enhanced chemiluminescence (BioRad Laboratories, USA) and exposed to X-ray film (Eastman-Kodak, Rochester, NY, USA).

\section{RNA isolation and library preparation and sequencing}

Total RNA was isolated using TRIzol reagent (Invitrogen). RNA quality was assessed using the Agilent 2100 bioanalyzer with the RNA 6000 Nano Chip (Agilent Technologies, Amstelveen, The Netherlands), and RNA quantification was performed using ND-2000 Spectrophotometer (Thermo Inc., DE, USA). For control and test RNAs, library construction was performed using the SENSE 3' mRNA-Seq Library Prep Kit (Lexogen, Inc., Austria) according to the manufacturer's instructions. Briefly, $500 \mathrm{ng}$ total RNA was used and an oligodT primer containing an Illumina-compatible sequence at its $5^{\prime}$ end was hybridized to the RNA prior to reverse transcription. After degradation of the RNA template, second strand synthesis was initiated by a random primer containing an Illumina-compatible linker sequence at its $5^{\prime}$ end. The double-stranded DNA library was purified by using magnetic beads to remove all reaction components. The library was amplified to add the complete adapter sequences required for cluster generation. The finished library is purified from PCR components. High-throughput sequencing was performed as single-end 75 sequencing using NextSeq 500 (Illumina, Inc., USA).

\section{Data analysis}

SENSE 3' mRNA-Seq reads were aligned using Bowtie2 version 2.1.0 (Langmead and Salzberg, 2012). Bowtie 2 indices were either generated from genome assembly sequences or the representative transcript sequences for aligning to the genome and the transcriptome. The alignment file was used for assembling transcripts, estimating their abundances and detecting differential expression of genes. Differentially expressed genes were determined based on counts from unique and multiple alignments using EdgeR in $\mathrm{R}$ version 3.2.2 ( $\mathrm{R}$ development Core Team, 2011) using BIOCONDUCTOR version 3.0 [28]. The read count (RT) data were processed based on quantile normalization method using the Genowiz ${ }^{\mathrm{TM}}$ version 4.0.5.6 (Ocimum Biosolutions, India). Cytoscape (version 2.7), an open-source bioinformatics platform developed by the Institute of Systems Biology (Seattle, WA) was used to construct network diagrams and to illustrate clustering of the genes in our dataset within specific pathways. Gene classification was based on searches done by DAVID (http://david.abcc.ncifcrf.gov/) and Medline databases (http://www.ncbi.nlm.nih.gov/). Experimental data were integrated and analyzed using ClueGO application within the Cytoscape plug-ins. ClueGO functional analysis was performed using Gene Ontology or using the Kyoto Encyclopedia of Genes and Genomes (KEGG).

\section{Statistical analysis}

All data are expressed as mean \pm standard deviation (S.D.). One-way ANOVA was used for multiple comparisons, using SPSS software v. 10.0. $P$ values $<0.05$ were considered significant. 


\section{Results}

Fabrication and characterization of iNOS-loaded mineralized nanoparticles

The iNOS-MNPs were fabricated using a PEG-PAsp-templated $\mathrm{CaCO}_{3}$ mineralization approach developed in our laboratory [29]. The addition of $\mathrm{Ca}^{2+}$ and $\mathrm{CO}_{3}{ }^{2-}$ ions to a stirred solution of PEG-PAsp induced ionic supersaturation around the anionic moieties of the PAsp blocks. This process induced the nucleation and growth of a crystalline $\mathrm{CaCO}_{3}$ core, while the PEG block formed the hydrated shell domains. During this mineralization process, iNOS could be loaded in situ within the $\mathrm{CaCO}_{3}$ core through ionic interaction. The mean hydrodynamic diameter of the iNOS-MNPs estimated by dynamic light scattering analyses was $333.9 \pm 10.2$ $\mathrm{nm}$ with a narrow polydispersity factor (0.11) (Fig. 1A). TEM analysis revealed that the iNOSMNPs have a spherical shape (Fig. 1B). The loading efficiency of iNOS in the iNOS-MNPs was estimated to be $35.1 \%$. For iNOS loading, the loading approach that does not induce the denaturation of iNOS is critical for stable iNOS delivery into ESCs. FT-IR analysis showed that the iNOS-MNPs showed vibration bands at $877 \mathrm{~cm}^{-1}$, which was attributed to the $\mathrm{v}_{2}$ (out-ofplane bending mode) bands of vaterite (Fig. 1C). We also observed the vibrational band at $1420 \mathrm{~cm}^{-1}$ attributed to $\mathrm{v}_{3}$ asymmetric stretching mode of the vaterite $\mathrm{CaCO}_{3}$.

pH-dependent catalytic activity of iNOS-MNPs for NO generation

We used the assay kit employing recombinant nitrate reductase for conversion of nitrates to nitrites prior to quantification of nitrite using the Griess reagent, thereby accurately evaluating overall iNOS activity. The pH-dependent catalytic activity of the iNOS-MNPs for

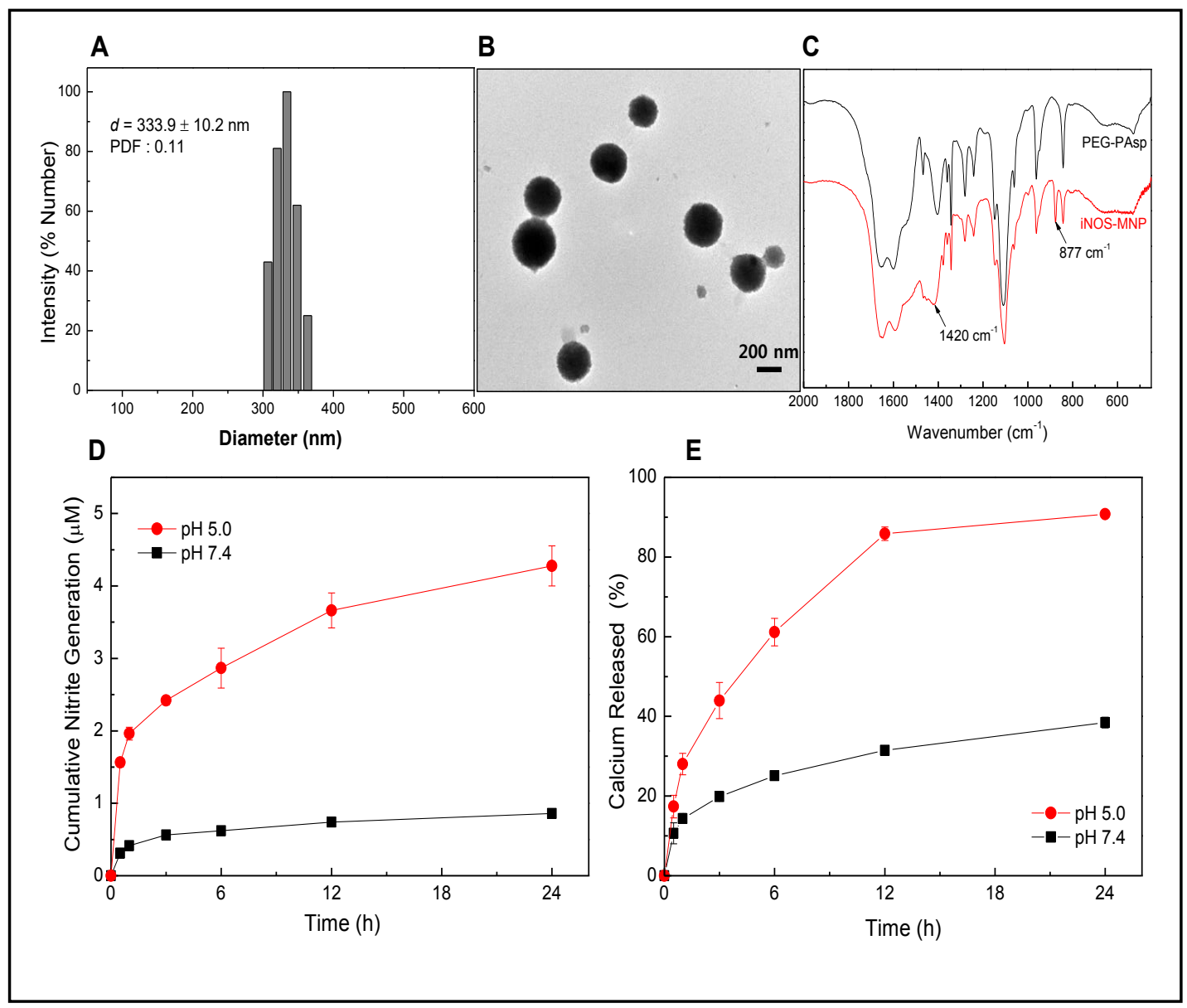

Fig. 1. Characteristics of the iNOS-MNPs. (A) Size distribution by dynamic light scattering, (B) TEM image, and (C) FT-IR spectra. (D) pH-dependent profiles of nitrite generation by iNOS-MNPs at pH values of 5.0 and $7.4(n=3)$ and $(E)$ kinetics of $\mathrm{CaCO}_{3}$ dissolution of the iNOS-MNPs at pH 5.0 and $7.4(\mathrm{n}=3)$. 


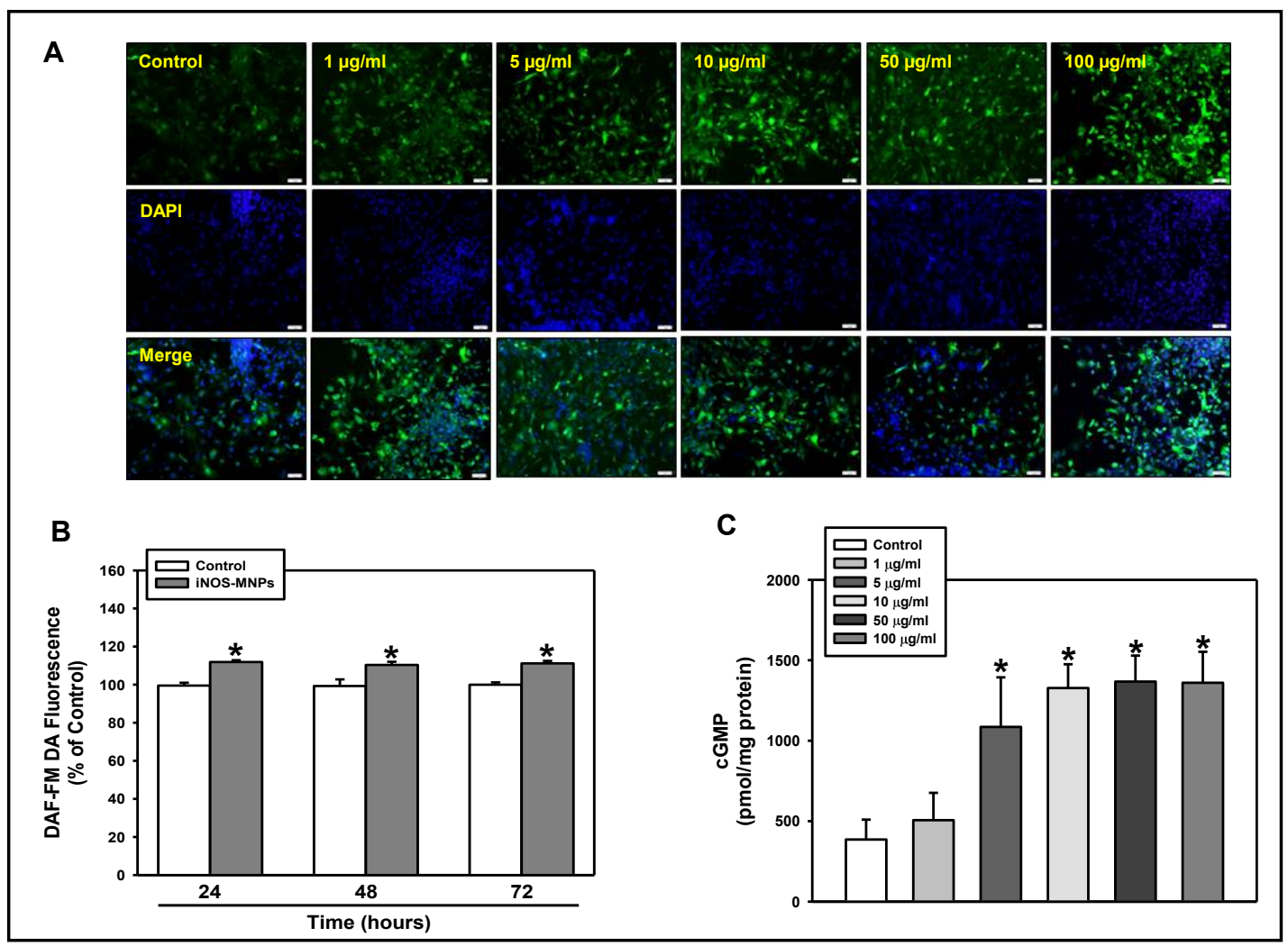

Fig. 2. Effects of iNOS-MNP on intracellular NO generation. The cells were incubated with different iNOS-MNP concentrations $(1,5,10,50$, and $100 \mu \mathrm{g} / \mathrm{ml})$ for 24,48 , or $72 \mathrm{~h}$. Using the fluorescent indicator, DAF-FM DA, intracellular NO levels were assessed by (A) fluorescence microscopic images and (B) fluorescence intensity assay. (C) cGMP concentrations were analyzed as described in Materials and Methods. A representative result from three independent experiments is shown (scale bar, $100 \mu \mathrm{m}$ ). The values reported are the mean \pm S.D. of four independent experiments. ${ }^{*} \mathrm{P}<0.05$ compared to the control value.

NO generation was estimated by evaluating the activity for generation of nitrite at both the extracellular $\mathrm{pH}$ (7.4) and the endosomal $\mathrm{pH}$ (5.0). Fig. 1D shows the $\mathrm{pH}$-dependent nitrite generation profiles at $\mathrm{pH} 7.4$ and 5.0. It is noteworthy that the nitrite generation at $\mathrm{pH} 5.0$ is more pronounced compared with that at $\mathrm{pH}$ 7.4. This enhanced nitrite generation at $\mathrm{pH}$ 5.0 indicates that a large amount of iNOS was released from the iNOS-MNPs, thus effectively catalyzing the oxidation of L-arginine to generate NO molecules. The improved activity at endosomal pH may indicate that the iNOS-MNPs can effectively generate NO molecules after internalization into ESCs. This indicates that iNOS was stably loaded within the $\mathrm{CaCO}_{3}$ cores and also released, while maintaining its inherent activity. To support the pH-dependent catalytic iNOS activity for $\mathrm{NO}$ generation, the kinetics of $\mathrm{CaCO}_{3}$ dissolution from the iNOSMNPs was examined. As shown in Fig. $1 \mathrm{E}$, at endosomal $\mathrm{pH}, \mathrm{CaCO}_{3}$ dissolution was facilitated, whereas $\mathrm{CaCO}_{3}$ dissolution was found to be inhibited at an extracellular $\mathrm{pH}$. Accelerated dissolution of the $\mathrm{CaCO}_{3}$ core at endosomal $\mathrm{pH}$ was expected because the solubility of $\mathrm{CaCO}_{3}$ increases in proportion to the concentration of protons $\left(\mathrm{H}^{+}\right)[30]$. Facilitated dissolution of $\mathrm{CaCO}_{3}$ at the endosomal $\mathrm{pH}$ triggered preferential iNOS release within ESCs, thereby resulting in the enhanced NO generation.

\section{Effect of iNOS-MNPs on intracellular NO levels}

To verify whether NO is successfully generated when cells uptake iNOS-MNPs, intracellular NO production is evaluated by using the cell-permeable fluorescent indicator DAF-FM DA for 24, 48, or $72 \mathrm{~h}$. When cells stained with DAF-FM DA were recorded by fluorescence microscopy, fluorescence was much stronger in cells treated with iNOS-MNPs than in the control group (Fig. 2A). Fluorescence intensity was higher in cells treated with iNOS-MNPs compared with control MNP-treated cells (without iNOS) at each time point 
(Fig. 2B). Intracellular levels of cGMP, a NO effector molecule were further evaluated. Cells with iNOS-MNPs displayed a significant increase in cGMP concentration compared with the control group (Fig. 2C). These results clearly indicate that cells successfully uptake the iNOSMNPs and that iNOS-MNPs promote NO production in ESCs.

\section{Induction of ESC osteogenic differentiation by iNOS-MNPS}

Prior to assessment of osteogenic activity of ESCs, cell viability in response to iNOS-MNP treatment was determined. Viability was unaffected in cells treated with different doses of iNOS-MNPs $(1,5,10,50$, and $100 \mu \mathrm{g} / \mathrm{ml})$ for $24 \mathrm{~h}$ (Fig. 3A).

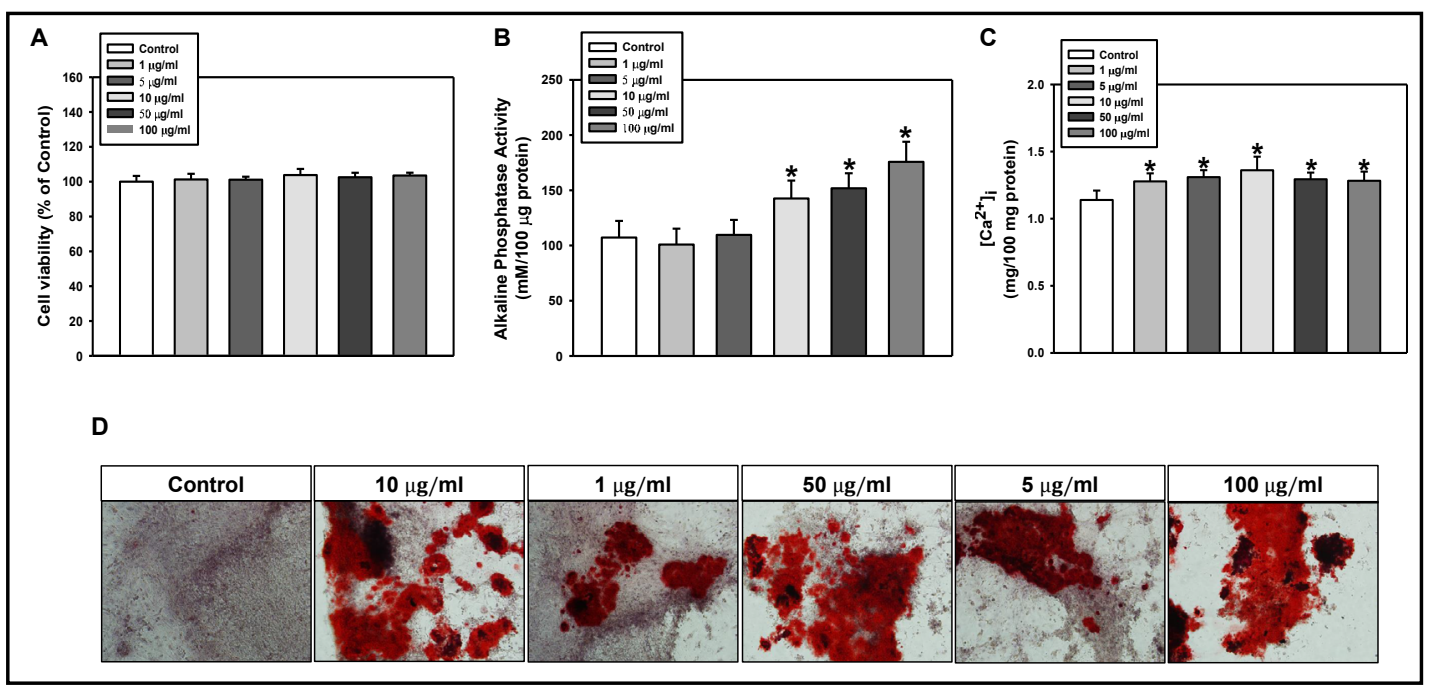

Fig. 3. Effect of iNOS-MNP on ESC-osteogenic differentiation. The cells were treated with different doses of iNOS-MNPs $(1,5,10,50$, and $100 \mu \mathrm{g} / \mathrm{ml})$ for cell viability assessment at $24 \mathrm{~h}$ (A) or 7-day osteogenic induction and (B) ALP activity, (C) $\left[\mathrm{Ca}^{2+}\right]_{i}$, and (D) Alizarin red staining was assessed. The values are reported as mean \pm S.D. of three independent experiments; ${ }^{*} \mathrm{P}<0.05$ compared to the control value.

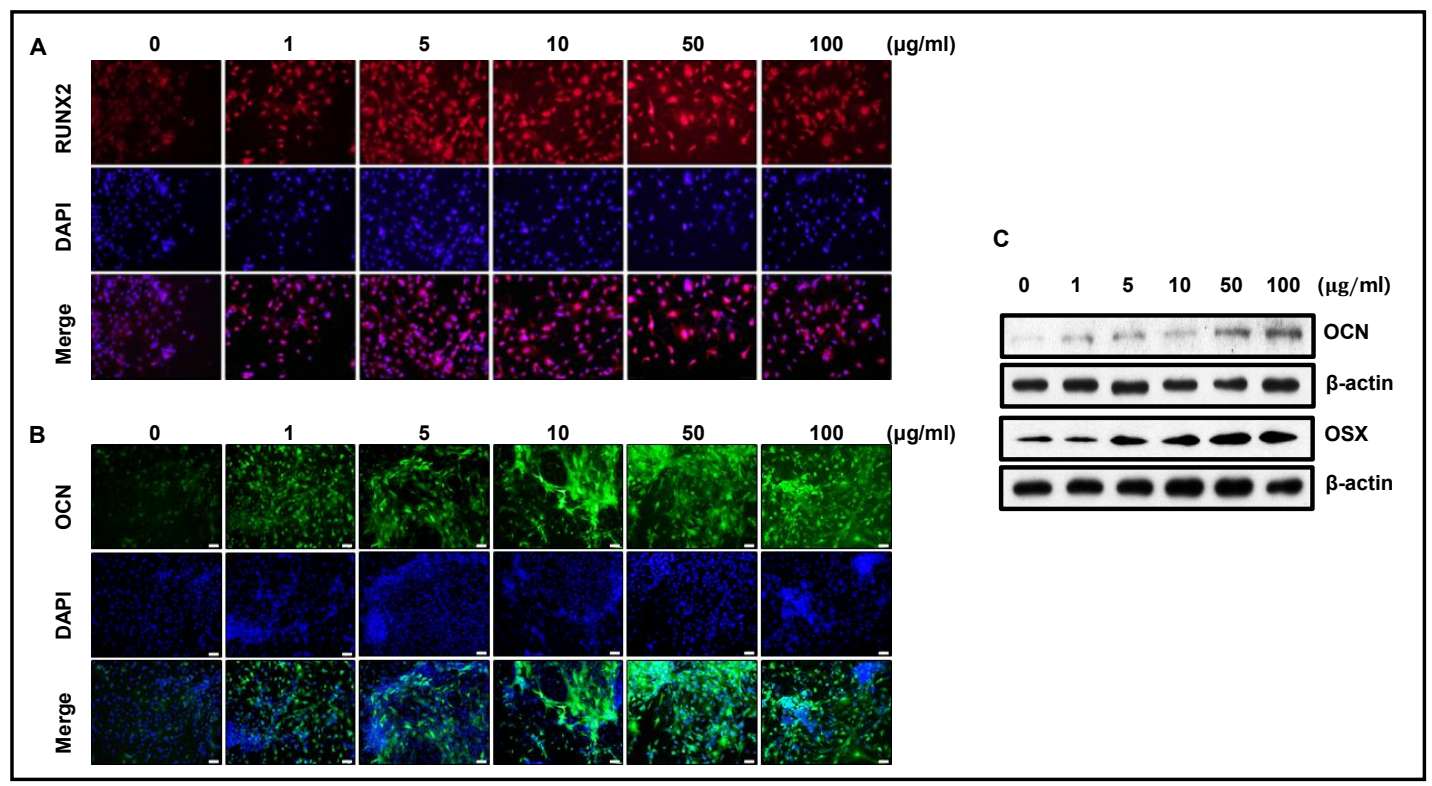

Fig. 4. Effect of iNOS-MNP on osteogenesis-related protein levels. The protein levels of RUNX2, OCN, and OSX were determined by immunofluorescence staining and western blotting. The nuclei were stained with DAPI (shown in blue). A representative result from three independent experiments is shown (scale bar, 100 $\mu \mathrm{m})$. 


\section{Cellular Physiology Cell Physiol Biochem 2018;51:746-762

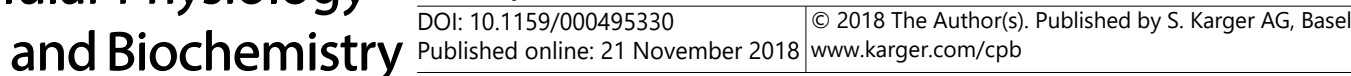 \\ Lee et al.: Effect of iNOS-MNP-Derived NO on ESC Osteogenesis}

To verify the osteogenic effect of iNOS-MNP on ESCs, cells were exposed to $1-100 \mu \mathrm{g} / \mathrm{ml}$ of iNOS-MNPs for 7, 14, or 21 days. ALP activity, $\left[\mathrm{Ca}^{2+}\right]_{i}$, and mineralization was then determined.

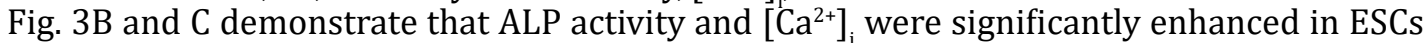
exposed to iNOS-MNPs. Cells treated for 21 days with iNOS-MNPs displayed highly positive Alizarin red S staining, suggesting high calcium nodule formation and matrix mineralization as would be expected as a result of osteogenic differentiation (Fig. 3D). To further identify osteogenic differentiation, we assessed the protein levels of osteogenic markers RUNX2, OCN, and OSX on day 7 of osteogenic induction. Immunofluorescence staining (Fig. 4A, B) and western blot analysis (Fig. 4C) confirmed that the treatment of iNOS-MNPs increased each osteogenic marker protein in ESCs compared with control group. These results suggest that the treatment of ESCs with iNOS-MNPs enhances osteogenic differentiation.

\section{iNOS-MNPs alter ESC transcription profile}

In order to investigate the changes in global gene expression by the iNOS-MNP-induced ESC differentiation, cells were treated with iNOS-MNPs for 14 days and high-throughput RNA-Seq analysis was performed. When a fold-change cut-off of $>1.5$ and a $P$ value of $<0.05$ was applied to filter the differentially expressed genes in iNOS-MNP-treated cells compared to the control, we classified 730 genes as upregulated and 1,106 as downregulated, which were clustered using the Euclidean distance correlation and visualized by a heatmap (Fig. 5A, B). Table 1 shows the top 10 upregulated or downregulated genes analyzed by the GO annotations using DAVID (http://david.abcc.ncifcrf.gov/). iNOS-MNP treatment induced the upregulation of genes associated with chemical homeostasis, but downregulated genes associated with regulation of the system process, suggesting that these actions downstream of iNOS-MNPs may control biological function. The gene lists and GO term data are presented in Supplemental Data 1 (For all supplemental material see www.karger. com/10.1159/000495330/).

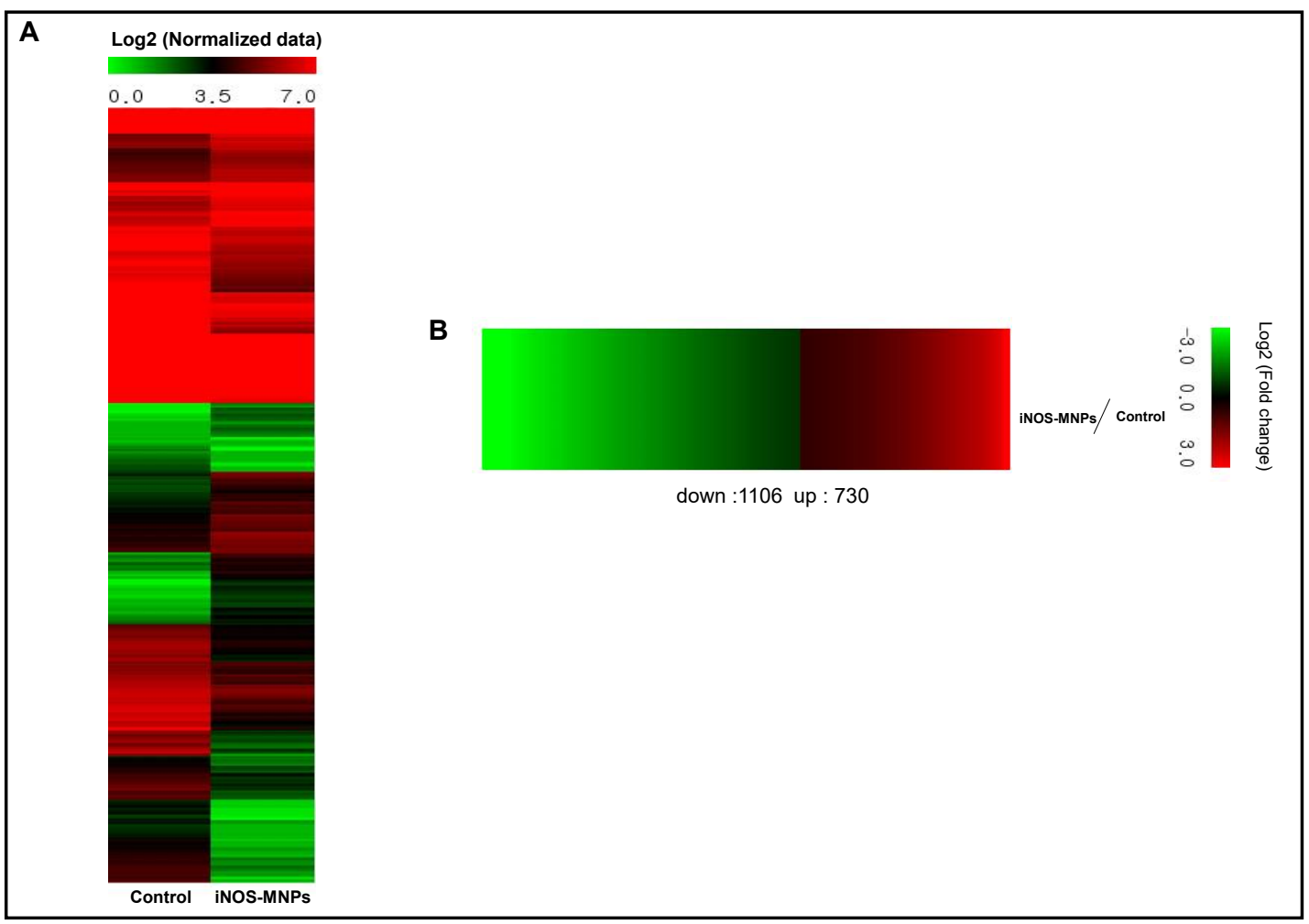

Fig. 5. RNA-Seq analysis of the cells cultured with iNOS-MNPs. (A) Clustering analysis was performed for the significantly regulated probe sets, consisting of the 1,836 genes. The color key indicates gene expression value (red for upregulated and green for downregulated). (B) Numbers of upregulated and downregulated genes in cells treated with iNOS-MNPs compared to those in control conditions with at least a 1.5-fold change in expression level. 
Identification of genes associated with osteogenic differentiation by iNOSMNPS

We next identified differentially expressed genes $(P<0.05$, with foldchange $>1.5)$ to extract the activation of bone-related molecular pathways by iNOS-MNP treatment, comprising a total of 537 genes, of which 337 were downregulated and 200 were upregulated using GO analysis (https:// www.ebi.ac.uk/QuickGO/) and ExDEGA (Excel-based Differentially Expressed Gene Analysis) version 2.3 tool (ebiogen, Korea) (Supplemental Data 2). Table 2 demonstrates the representative genes which were mapped to 14 different pathways such as cell differentiation, proliferation, extracellular matrix, BMP signaling, calcium ion binding, calciummediated signaling, mitogen-activated protein kinase (MAPK) cascade, Notch signaling, vasculature development, Wnt signaling, cell adhesion, growth factor activity, ossification, and skeletal system development, all of which are related to osteogenic differentiation and bone formation. The RNA-Seq data were validated by evaluating the expression of selected genes (Mmp15, Cltb, Atp5s, Cadn4, Wnt9a, Bmp8a, Fgf11, Map4k1) using real-time RT-PCR analysis. These genes were upregulated in a similar manner as that observed with RNA-Seq analysis, thus validating the RNA-Seq data (Fig. 6).

\section{Evaluation of the connectivity network between the differentially expressed genes}

Network-based analysis within the differentially expressed genes relating to the osteogenic differentiation-related molecular pathways was further extracted by ClueGO. The molecular functions such as protein kinase activity, estrogen receptor activity, BMP receptor binding, ligand-gated ion channel activity, or phosphatidylinositol 3-phosphate binding were shown to be significantly enriched and interconnected (Fig. S1). We next performed pathway enrichment analysis and identified the networks of three significantly enriched KEGG pathways along with the genes shared between these pathways (Fig. S2A). Fig. S2-B illustrates the number of genes associated with each term in significant KEGG pathways. These analyses identify several pathways and genes with a connection to cellular mechanisms that are associated with NO-mediated ESC-osteogenic differentiation.
Table 1. Top 10 annotation clusters for upregulated and downregulated genes in cells treated with iNOSNPs compared to those in control conditions with associated $P$ values from DAVID GO term analysis

\begin{tabular}{lc}
\hline Term & -log10 (p-value) \\
\hline Top GO term of top 10 annotation clusters for up regulated gene & \\
GO:0006334 nucleosome assembly & $3.63 \mathrm{E}+00$ \\
GO:0032776 DNA methylation on cytosine & $2.65 \mathrm{E}+00$ \\
GO:0006335 DNA replication-dependent nucleosome assembly & $2.59 \mathrm{E}+00$ \\
GO:0045815 positive regulation of gene expression, epigenetic & $2.59 \mathrm{E}+00$ \\
GO:0007275 multicellular organism development & $2.31 \mathrm{E}+00$ \\
GO:0051290 protein heterotetramerization & $1.93 \mathrm{E}+00$ \\
GO:0006206 pyrimidine nucleobase metabolic process & $1.79 \mathrm{E}+00$ \\
GO:0006471 protein ADP-ribosylation & $1.71 \mathrm{E}+00$ \\
GO:0006081 cellular aldehyde metabolic process & $1.67 \mathrm{E}+00$ \\
GO:0000183 chromatin silencing at rDNA & $1.65 \mathrm{E}+00$ \\
& \\
Top GO term of top 10 annotation clusters for down regulated gene & \\
GO:0034765 regulation of ion transmembrane transport & $5.15 \mathrm{E}+00$ \\
GO:0006816 calcium ion transport & $3.79 \mathrm{E}+00$ \\
GO:0006811 ion transport & $3.77 \mathrm{E}+00$ \\
GO:0032729 positive regulation of interferon-gamma production & $3.72 \mathrm{E}+00$ \\
GO:0007612 learning & $3.57 \mathrm{E}+00$ \\
GO:0006836 neurotransmitter transport & $3.45 \mathrm{E}+00$ \\
GO:0051965 positive regulation of synapse assembly & $3.36 \mathrm{E}+00$ \\
GO:0050804 modulation of synaptic transmission & $3.16 \mathrm{E}+00$ \\
GO:0070588 calcium ion transmembrane transport & $3.13 \mathrm{E}+00$ \\
GO:0019233 sensory perception of pain & $3.03 \mathrm{E}+00$ \\
\hline
\end{tabular}

\author{
.
}


Lee et al.: Effect of iNOS-MNP-Derived NO on ESC Osteogenesis

Table 2. List of the most representative genes and pathways. red, up-regulated genes; blue, down-regulated genes

\begin{tabular}{|c|c|c|c|}
\hline Gene symbol & Fold change & Gene name & Pathway \\
\hline Mfrp & 10.727 & membrane-type frizzled-related protein & \\
\hline $\mathrm{Tlx} 2$ & 8.810 & T cell leukemia, homeobox 2 & \\
\hline Nkx2-3 & 6.667 & NK2 transcription factor related, locus 3 (Drosophila) & Cell differentiation \\
\hline H2-DMa & 6.444 & histocompatibility 2 , class II, locus DMa & \\
\hline Ecscr & 5.889 & endothelial cell surface expressed chemotaxis and apoptosis & \\
\hline Six2 & 3.840 & sine oculis-related homeobox 2 & \\
\hline Slc11a1 & 3.680 & solute carrier family 11 , member 1 & \\
\hline Fam83a & 3.444 & family with sequence similarity 83 , member $A$ & Cell proliferation \\
\hline Mov10l1 & 3.267 & Moloney leukemia virus 10 -like 1 & \\
\hline Tspan1 & 2.695 & tetraspanin 1 & \\
\hline Ahsg & 9.937 & alpha-2-HS-glycoprotein & \\
\hline Rarres 2 & 6.391 & retinoic acid receptor responder 2 & \\
\hline Sod3 & 6.368 & superoxide dismutase 3 , extracellular & Extracelluar matrix \\
\hline Lrrc55 & 5.760 & leucine rich repeat containing 55 & \\
\hline Wnt10a & 4.804 & wingless related MMTV integration site $10 \mathrm{a}$ & \\
\hline Bmp8a & 4.784 & bone morphogenetic protein $8 \mathrm{a}$ & \\
\hline Chrd & 2.387 & chordin & BMP signaling nathway \\
\hline Bmp2 & 0.567 & bone morphogenetic protein 2 & Bivir Signaming patnway \\
\hline Lef1 & 0.288 & lymphoid enhancer binding factor 1 & \\
\hline Cabp2 & 16.722 & calcium binding protein 2 & \\
\hline Cdhr5 & 6.000 & cadherin-related family member 5 & \\
\hline Pcdhb5 & 5.619 & protocadherin beta 5 & Calcium ion binding \\
\hline Thbs 4 & 4.545 & thrombospondin 4 & \\
\hline S100a16 & 4.004 & S100 calcium binding protein A16 & \\
\hline Jph2 & 2.296 & junctophilin 2 & Calcium mediated signaling \\
\hline Nrg1 & 4.197 & neuregulin 1 & \\
\hline Slc11a1 & 3.680 & solute carrier family 11 , member 1 & \\
\hline Map3k6 & 3.008 & mitogen-activated protein kinase kinase kinase 6 & MAPK cascade \\
\hline Mapk4 & 2.632 & mitogen-activated protein kinase 4 & \\
\hline Map4k1 & 2.618 & mitogen-activated protein kinase kinase kinase kinase 1 & \\
\hline Hes7 & 4.636 & hairy and enhancer of split 7 (Drosophila) & \\
\hline Jag2 & 3.912 & jagged 2 & \\
\hline Dtx2 & 1.855 & deltex 2 homolog (Drosophila) & Notch signaling pathway \\
\hline Rbm15 & 1.734 & RNA binding motif protein 15 & \\
\hline Ubb & 1.544 & ubiquitin B & \\
\hline Aqp1 & 9.222 & aquaporin 1 & \\
\hline Ecscr & 5.889 & endothelial cell surface expressed chemotaxis and apoptosis & \\
\hline $\mathrm{Cdx} 2$ & 3.545 & caudal type homeobox 2 & Vasculature development \\
\hline Hoxb13 & 3.520 & homeobox B13 & \\
\hline Pgf & 3.337 & placental growth factor & \\
\hline Wnt10a & 4.804 & wingless related MMTV integration site $10 \mathrm{a}$ & \\
\hline Wnt9a & 2.323 & wingless-type MMTV integration site 9A & \\
\hline Cela1 & 2.042 & chymotrypsin-like elastase family, member 1 & Wnt signaling pathway \\
\hline Axin 2 & 1.558 & axin2 & \\
\hline Ccnd1 & 0.620 & cyclin D1 & \\
\hline Nkx2-3 & 6.667 & NK2 transcription factor related, locus 3 (Drosophila) & \\
\hline H2-DMa & 6.444 & histocompatibility 2 , class II, locus DMa & \\
\hline Lims 2 & 6.036 & LIM and senescent cell antigen like domains 2 & Cell adhesion \\
\hline Cdhr5 & 6.000 & cadherin-related family member 5 & \\
\hline Pcdhb5 & 5.619 & protocadherin beta 5 & \\
\hline Fgf11 & 5.067 & fibroblast growth factor 11 & \\
\hline Bmp8a & 4.784 & bone morphogenetic protein $8 \mathrm{a}$ & \\
\hline Thbs 4 & 4.545 & thrombospondin 4 & Growth factor activity \\
\hline Nrg1 & 4.197 & neuregulin 1 & \\
\hline Jag2 & 3.912 & jagged 2 & \\
\hline Ahsg & 9.937 & alpha-2-HS-glycoprotein & \\
\hline Bmp8a & 4.784 & bone morphogenetic protein $8 \mathrm{a}$ & \\
\hline Asgr2 & 2.818 & asialoglycoprotein receptor 2 & Ossification \\
\hline Chrd & 2.387 & chordin & \\
\hline Sbds & 1.646 & Shwachman-Bodian-Diamond syndrome homolog (human) & \\
\hline Bmp8a & 4.784 & bone morphogenetic protein $8 \mathrm{a}$ & \\
\hline Hes7 & 4.636 & hairy and enhancer of split 7 (Drosophila) & \\
\hline Jag2 & 3.912 & jagged 2 & Skeletal system development \\
\hline Six2 & 3.840 & sine oculis-related homeobox 2 & \\
\hline Mks1 & 2.835 & Meckel syndrome, type 1 & \\
\hline
\end{tabular}




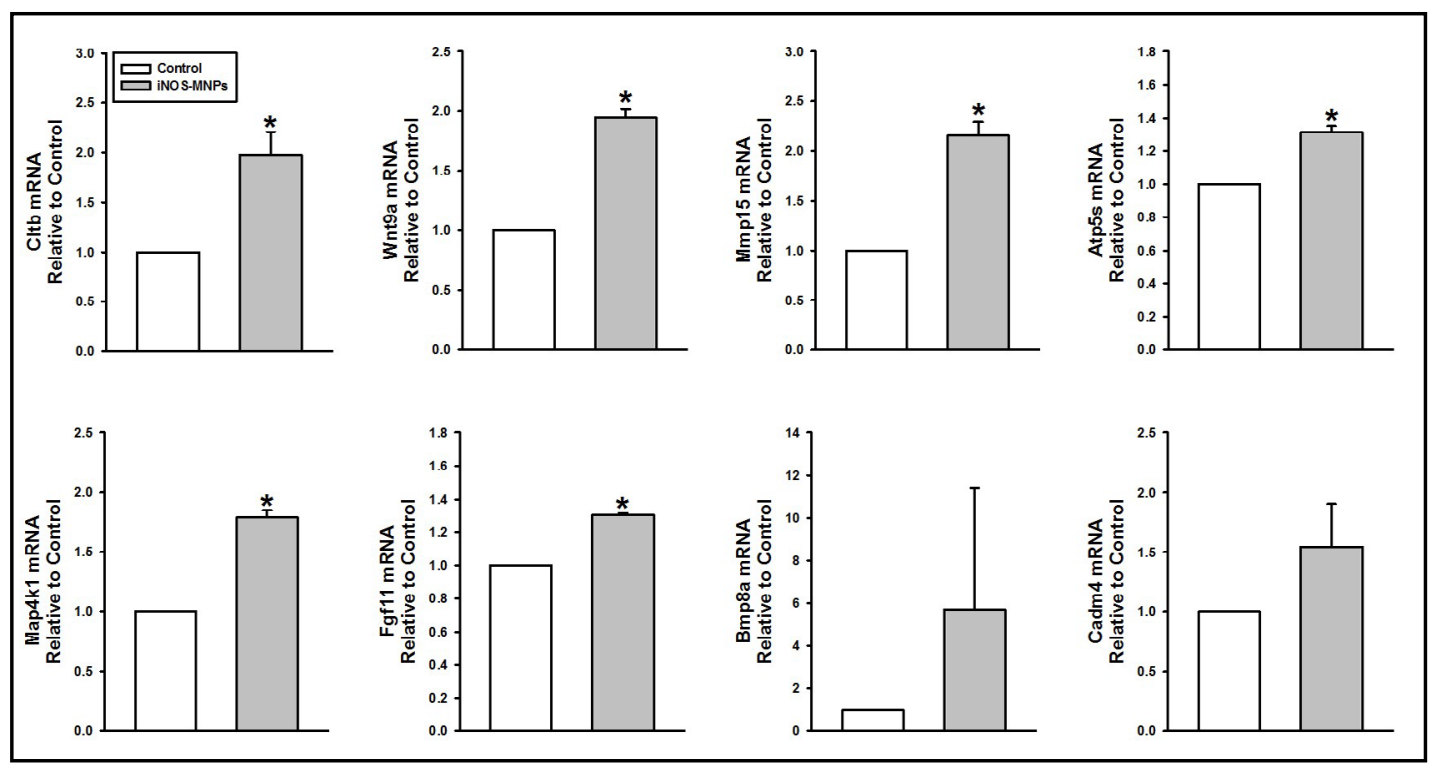

Fig. 6. Real-time RT-PCR validation for RNA-seq data. Eight genes (Mmp15, Cltb, Atp5s, Cadn4, Wnt9a, Bmp8a, Fgf11, Map4k1) were evaluated by real time RT-PCR and show similar pattern of expression as predicted by the RNA-seq. The values are reported as means \pm SD of three independent experiments; ${ }^{*} \mathrm{P}<0.05$ compared to the control value.

\section{Discussion}

The present study determined the performance of iNOS-loaded nanoparticles on osteogenic differentiation and molecular function assessed using a genome-wide approach in ESCs. We first demonstrated successful intracellular iNOS/NO pathway induction by iNOSMNP uptake and considerable effect of iNOS-MNPs-derived NO levels on differentiation of ESCs into osteogenic lineage, suggesting that NO can be a significant osteogenic cue in ESCs. NO plays an important role in osteogenesis, bone remodeling, and other metabolic mechanisms $[13,31,32]$. Several studies reported that NO stimulates the proliferation and differentiation of mesenchymal stem cells and calvarial osteoblasts [33, 34]. Treatment with a NO donor upregulates proliferation in human osteoblast cells and fetal calvarial osteoblasts $[35,36]$. The crucial role of NO and NOS isoforms on ESC-osteogenic differentiation was previously reported and is comparable to our findings [20]. NO involvement in osteogenic development has been extensively explored, but how NO bioavailability impinges on the osteogenic program at the transcriptional levels has not been precisely elucidated.

We demonstrated that the increased NO levels induced by iNOS-MNPs influenced an extensive transcriptomic effect during the osteogenic differentiation process. Transcriptional analysis described differentially regulated pathways that may play important roles in NO-mediated osteogenic differentiation of ESCs. Among the activated pathways, MAPK signaling pathways promote the osteogenesis of stem cells in other experimental systems. Osteogenesis in human mesenchymal stem cells was improved by bioflavonoid treatment through the activation of c-Jun N-terminal kinase (JNK) and p38 MAPK pathways [37]. Inorganic nanoparticles such as those composed of gold or iron stimulate the osteogenesis of human periodontal ligament stem cells (PDLSCs) or human bone marrow stromal cells (BMSCs) in vitro via the p38 MAPK or extracellular signal-regulated kinase 1/2 (ERK1/2) activation [38, 39]. Similar to our results, co-activation of NO, BMP2, and MAPK pathways are involved in osteoblast proliferation and differentiation downstream of phytoestrogeninduced osteogenesis [40]. NO is known to induce osteogenesis of ESCs through activation of canonical Wnt signaling [21]. More recently, our group has reported that Wnt signaling is associated with the osteogenic differentiation of stem cells under various experimental conditions [41-43]. Based on previous studies and our present data, we suggest that NO can activate wide spectrum of signaling pathways involved in the osteogenic differentiation of stem cells. 
This study also provides molecular insights into the network of differentially expressed genes that may act downstream of NO to induce osteogenesis in ESCs. Through functional enrichment, we identified that NO can induce multiple molecular pathways such as protein kinase activity, estrogen receptor activity, BMP receptor binding, ligand-gated ion channel activity, or phosphatidylinositol 3-phosphate binding. Consistent with our results, many studies have demonstrated the relationship between NO and estrogen receptor signaling in several biological processes including osteogenic development [44-46]. Moreover, BMP signaling-induced NO production stimulated bone calcification in zebrafish [47]. BMP receptor type II ligands (i.e., BMP-2 and BMP-4) can stimulate NOS activity [48]. Ultimately, when differentially expressed genes were assigned to pathways using the KEGG mapper, we found three NO-driven pathways, namely the Rap1 and PI3K-Akt signaling pathways, and focal adhesion, which links different pathways. Previous studies have reported the connection between NO and these signaling pathways in osteoblastic activity [49-52]. Thus, we suggest that the NO signaling molecule can drive genetic and molecular pathways with implicated roles in ESC-osteogenic differentiation.

\section{Conclusion}

Our study demonstrated that the application of iNOS-loaded nanoparticles promoted ESC differentiation into the osteogenic lineage and identified putative genes and pathway networks involved in this osteoinduction. These findings provide a framework for identifying novel mechanisms by which iNOS/NO induces ESC-osteogenic differentiation. In addition, manipulating iNOS-derived NO signaling pathways using nanomaterials represent novel tools for the generation of lineage-committed cells for use in regenerative cell therapies.

\section{Abbreviations}

iNOS-MNPs (Nitric oxide synthase-loaded mineralized nanoparticles); ESCs (Embryonic stem cells); NO (Nitric oxide); cGMP (cyclic guanosine 3',5' monophosphate); ALP (Alkaline phosphatase); $\left[\mathrm{Ca}^{2+}\right]_{\mathrm{i}}$ (Intracellular calcium levels); RUNX2 (Runt-related transcription factor 2); OCN (Osteocalcin); OSX (osterix); KEGG (Kyoto Encyclopedia of Genes and Genomes); BMP (Bone morphogenetic protein).

\section{Acknowledgements}

This work was supported by a National Research Foundation of Korea (NRF) grant funded by the Korea government (MSIP) (No. 2015R1A2A2A01006490) and the Bio \& Medical Technology Development Program of the NRF funded by the Korea government (MSIP\&MOHW) (No. 2017M3A9E4048170).

\section{Disclosure Statement}

All of the authors declare that there are no competing interests.

\section{References}

$>1$ Bredt DS: Endogenous nitric oxide synthesis: biological functions and pathophysiology. Free Radic Res 1999;31:577-596.

-2 Förstermann U, Gath I, Schwarz P, et al: Isoforms of nitric oxide synthase. Properties, cellular distribution and expressional control. Biochem Pharmacol 1995;50:1321-1332. 


\section{Cellular Physiology Cell Physiol Biochem 2018;51:746-762 and Biochemistry \begin{tabular}{l|l} 
DOI: $10.1159 / 000495330$ & 2018 The Author(s). Published by S. Karger AG, Basel
\end{tabular}

Lee et al.: Effect of iNOS-MNP-Derived NO on ESC Osteogenesis

- W Wang FS, Kuo YR, Wang CJ, Yang KD, Chang PR, Huang YT, Huang HC, Sun YC, Yang YJ, Chen YJ: Nitric oxide mediates ultrasound-induced hypoxia-inducible factor-1alpha activation and vascular endothelial growth factor-A expression in human osteoblasts. Bone 2004;35:114-123.

$\checkmark 4$ Saura M, Tarin C, Zaragoza C: Recent insights into the implication of nitric oxide in osteoblast differentiation and proliferation during bone development. Scientific World Journal 2004;10:624-632.

5 Corbett SA, Hukkanen M, Batten J, et al: Nitric oxide in fracture repair. Differential localisation, expression and activity of nitric oxide synthases. J Bone Joint Surg Br 1999;81-B:531-537.

-6 Diwan AD, Wang MX, Jang D, et al: Nitric oxide modulates fracture healing. J Bone Miner Res 2000;15:342351.

7 Zhu W, Murrell GA, Lin J, et al: Localization of nitric oxide synthases during fracture healing. J Bone Miner Res 2002;17:470-477.

-8 Hukkanen M, Hughes FJ, Buttery LD, et al: Cytokine-stimulated expression of inducible nitric oxide synthase by mouse, rat, and human osteoblast-like cells and its functional role in osteoblast metabolic activity. Endocrinology 1995;136:5445-5453.

-9 Wimalawansa SJ: Nitric oxide and bone. Ann N Y Acad Sci 2010;1192:391-403.

10 Baldik Y, Diwan AD, Appleyard RC, et al: Deletion of iNOS gene impairs mouse fracture healing. Bone 2005;37:32-36.

11 Bryan NS, Bian K, Murad F: Discovery of nitric oxide signaling pathways and targets for drug development. Front Biosci 2009;14:1-18.

12 Murad F: Shattuck lecture: nitric oxide and cyclic GMP in cell signaling and drug development. N Engl J Med 2006;355:2003-2011.

13 Evans DM, Ralston SH: Nitric oxide and bone. J Bone Miner Res 1996;11:300-305.

14 Krumenacker JS, Kots A, Murad F: Differential expression of genes involved in cGMP-dependent nitric oxide signaling in murine embryonic stem (ES) cells and ES cell-derived cardiomyocytes. Nitric Oxide 2006;14:111.

15 Mujoo K, Sharin VG, Bryan NS, Krumenacker JS, Sloan C, Parveen S, Nikonoff LE, Kots A Y, Murad F: Role of nitric oxide signaling components in differentiation of embryonic stem cells into myocardial cells. Proc Natl Acad Sci USA 2008;105:18924-18929.

16 Mora-Castilla S, Tejedo JR, Hmadcha A, Cahuana GM, Martı́n F, Soria B, Bedoya FJ: Nitric oxide repression of Nanog promotes mouse embryonic stem cell differentiation. Cell Death Differ 2010;17:1025-1033.

17 Ocarino NM, Boeloni JN, Goes AM, Silva JF, Marubayashi U, Serakides R: Osteogenic differentiation of mesenchymal stem cells from osteopenic rats subjected to physical activity with and without nitric oxide synthase inhibition. Nitric Oxide 2008;19:320-325.

18 Joiner DM, Tayim RJ, Kadado A, Goldstein SA: Bone marrow stromal cells from aged male rats have delayed mineralization and reduced response to mechanical stimulation through nitric oxide and ERK1/2 signaling during osteogenic differentiation. Biogerontology 2012;13:467-478.

19 Zhang W, Liu J, Shi H, Yang K, Wang P, Wang G, Liu N, Wang H, Ji J, Chu PK: Communication between nitric oxide synthase and positively-charged surface and bone formation promotion. Colloids Surf B Biointerfaces 2016;148:354-362.

-20 Ehnes DD, Geransar RM, Rancourt DE, Zur Nieden NI: Exogenous nitric oxide enhances calcification in embryonic stem cell-derived osteogenic cultures. Differentiation 2015;89:97-103.

-21 Ding H, Keller KC, Martinez IK, Geransar RM, zur Nieden KO, Nishikawa SG, Rancourt DE, zur Nieden NI: NO- $\beta$-catenin crosstalk modulates primitive streak formation prior to embryonic stem cell osteogenic differentiation. J Cell Sci 2012;125:5564-5577.

22 Nakagawa H: Photocontrollable NO-releasing compounds and their biological applications. Journal of clinical biochemistry and nutrition 2016;58:2-6.

23 Kang Y, Kim J, Lee YM, Im S, Park H, Kim WJ: Nitric oxide-releasing polymer incorporated ointment for cutaneous wound healing. Journal of Controlled Release 2015;220:624-630.

24 Hawiger J: Cellular import of functional peptides to block intracellular signaling. Curr Opin Immunol 1997;9:189e94.

25 Noda T, Kawamura R, Funabashi H, Mie M, Kobatake E: Transduction of neuroD2 protein induced neural cell differentiation. J Biotechnol 2006;126:230e6.

26 Lock J, Liu H: Nanomaterials enhance osteogenic differentiation of human mesenchymal stem cells similar to a short peptide of BMP-7. Int J Nanomedicine 2011;6:2769-2777. 


\section{Cellular Physiology Cell Physiol Biochem 2018;51:746-762 \begin{tabular}{l|l|l|l|l} 
DOI: 10.1159/000495330 & ○ 2018 The Author(s). Published by S. Karger AG, Basel
\end{tabular}

-27 Bradford MM: A rapid and sensitive method for the quantitation of microgram quantities of protein utilizing the principle of protein-dye binding. Anal Biochem 1976;72:248-254.

28 Gentleman RC, Carey VJ, Bates DM, Bolstad B, Dettling M, Dudoit S, Ellis B, Gautier L, Ge Y, Gentry J, Hornik K, Hothorn T, Huber W, Iacus S, Irizarry R, Leisch F, Li C, Maechler M, Rossini AJ, Sawitzki G et al.: Bioconductor: open software development for computational biology and bioinformatics. Genome Biol 2004;5:R8.

29 Lee HJ, Kim da E, Park DJ, Choi GH, Yang DN, Heo JS, Lee SC: pH-Responsive mineralized nanoparticles as stable nanocarriers for intracellular nitric oxide delivery. Colloids Surf B Biointerfaces 2016;146:1-8.

-30 Goss SL, Lemons KA, Kerstetter JE, Bogner RH: Determination of calcium salt solubility with changes in $\mathrm{pH}$ and $\mathrm{P}(\mathrm{CO}(2))$, simulating varying gastrointestinal environments. J Pharm Pharmacol 2007;59:1485-1492.

-31 Taylor BC, Schreiner PJ, Zmuda JM, Li J, Moffett SP, Beck TJ, et al: Association of endothelial nitric oxide synthase genotypes with bone mineral density, bone loss, hip structure, and risk of fracture in older women: The SOF study Bone 2006;39:174-180.

-32 Wang CJ, Yang KD, Ko JY, Huang CC, Huang HY, Wang FS: The effects of shockwave on bone healing and systemic concentrations of nitric oxide (NO), TGF-beta1, VEGF and BMP-2 in long bone non-unions. Nitric Oxide 2009;20:298-303.

33 Sosroseno W, Sugiatno E, Samsudin AR, Ibrahim F: The role of nitric oxide on the proliferation of a human osteoblast cell line stimulated with hydroxyapatite. J OralImplantol 2008;34:196-202.

-34 Orciani M, Trubiani O, Vignini A, Mattioli-Belmonte M, DiPrimio R, Salvolini E: Nitric oxide production during the osteogenic differentiation of human periodontal ligament mesenchymal stem cells. Acta Histochem 2009;111:15-24.

35 Lin IC, Smartt JM Jr, Nah HD, Ischiropoulos H, Kirschner RE: Nitric oxide stimulates proliferation and differentiation of fetal calvarial osteoblasts and dural cells. Plast Reconstr Surg 2008;121:1554-1566.

-36 Sugiatno E, Samsudin AR, Sosroseno W: Effect of exogenous nitric oxide on the proliferation of a human osteoblast (HOS) cell line induced by hydroxyapatite. J Appl Biomater Biomech 2009;7:29-33.

37 Zha X, Xu Z, Liu Y, Xu L, Huang H, Zhang J, Cui L, Zhou C, Xu D: Amentoflavone enhances osteogenesis of human mesenchymal stem cells through JNK and p38 MAPK pathways. J Nat Med 2016;70:634-644.

38 Niu C, Yuan K, Ma R, Gao L, Jiang W, Hu X, Lin W, Zhang X, Huang Z: Gold nanoparticles promote osteogenic differentiation of human periodontal ligament stem cells via the p38 MAPK signaling pathway. Mol Med Rep 2017;16:4879-4886.

39 Wang Q, Chen B, Cao M, Sun J, Wu H, Zhao P, Xing J, Yang Y, Zhang X, Ji M, Gu N: Response of MAPK pathway to iron oxide nanoparticles in vitro treatment promotes osteogenic differentiation of hBMSCs. Biomaterials 2016;86:11-20.

40 Sheu SY, Tsai CC, Sun JS, Chen MH, Liu MH, Sun MG: Stimulatory effect of puerarin on bone formation through co-activation of nitric oxide and bone morphogenetic protein-2/mitogen-activated protein kinases pathways in mice. Chin Med J (Engl) 2012;125:3646-3653.

41 Kwon IK, Lee SC, Hwang YS, Heo JS: Mitochondrial function contributes to oxysterol-induced osteogenic differentiation in mouse embryonic stem cells. Biochim Biophys Acta 2015;1853:561-572.

42 Kook SH, Heo JS, Lee JC: Crucial roles of canonical Runx2-dependent pathway on Wnt1-induced osteoblastic differentiation of human periodontal ligament fibroblasts. Mol Cell Biochem 2015;402:213223.

43 Kim SY, Lee JY, Park YD, Kang KL, Lee JC, Heo JS: Hesperetin alleviates the inhibitory effects of high glucose on the osteoblastic differentiation of periodontal ligament stem cells. PLoS One 2013;8:e67504.

-44 Basudhar D, Somasundaram V, de Oliveira GA, Kesarwala A, Heinecke JL, Cheng RY, Glynn SA, Ambs S, Wink DA, Ridnour LA: Nitric Oxide Synthase-2-Derived Nitric Oxide Drives Multiple Pathways of Breast Cancer Progression. Antioxid Redox Signal 2017;26: 1044-1058.

45 Lv H, Che T, Tang X, Liu L, Cheng J: Puerarin enhances proliferation and osteoblastic differentiation of human bone marrow stromal cells via a nitric oxide/cyclic guanosine monophosphate signaling pathway. Mol Med Rep 2015;12:2283-2290.

46 Duluc L, Jacques C, Soleti R, Iacobazzi F, Simard G, Andriantsitohaina R: Modulation of mitochondrial capacity and angiogenesis by red wine polyphenols via estrogen receptor, NADPH oxidase and nitric oxide synthase pathways. Int J Biochem Cell Biol 2013;45:783-791. 


\section{Cellular Physiology Cell Physiol Biochem 2018;51:746-762

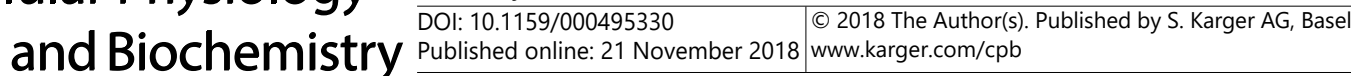

47 Windhausen T, Squifflet S, Renn J, Muller M: BMP Signaling Regulates Bone Morphogenesis in Zebrafish through Promoting Osteoblast Function as Assessed by Their Nitric Oxide Production. Molecules 2015;20:7586-7601.

48 Gangopahyay A, Oran M, Bauer EM, Wertz JW, Comhair SA, Erzurum SC, Bauer PM: Bone morphogenetic protein receptor II is a novel mediator of endothelial nitric-oxide synthase activation. J Biol Chem 2011;286:33134-33140.

49 Wu Y, Zhou J, Li Y, Zhou Y, Cui Y, Yang G, Hong Y: Rap1A Regulates Osteoblastic Differentiation via the ERK and p38 Mediated Signaling. PLoS One 2015;10:e0143777.

-50 Zhai YK, Guo XY, Ge BF, Zhen P, Ma XN, Zhou J, Ma HP, Xian CJ, Chen KM: Icariin stimulates the osteogenic differentiation of rat bone marrow stromal cells via activating the PI3K-AKT-eNOS-NO-cGMP-PKG. Bone 2014;66:189-198.

51 Ma P, Gu B, Xiong W, Tan B, Geng W, Li J, Liu H: Glimepiride promotes osteogenic differentiation in rat osteoblasts via the PI3K/Akt/eNOS pathway in a high glucose microenvironment. PLoS One 2014;9:e112243.

52 Ma XY, Feng YF, Wang TS, Lei W, Li X, Zhou DP, Wen XX, Yu HL, Xiang LB, Wang L: Involvement of FAKmediated BMP-2/Smad pathway in mediating osteoblast adhesion and differentiation on nano-HA/ chitosan composite coated titanium implant under diabetic conditions. Biomater Sci 2017;6:225-238. 